\title{
Adaptation and Factorial Validation of the Attitudes Toward Gender Roles Scale ${ }^{1}$
}

\author{
Claudia Andrade ${ }^{2}$ \\ Instituto Politécnico de Coimbra, \\ Coimbra, Portugal
}

\begin{abstract}
Attitudes toward gender roles result from a social construction process that has implications for the accepted gender role models for men and women. This study aims at the adaptation and factorial validation of a measurement scale for attitudes toward gender roles. The sample consisted of 746 college students and young professionals. Exploratory and confirmatory factor analyses were performed to check the scale's structure. A two-factor structure was found for the Attitudes toward Gender Roles Scale: the first factor reflects a traditional division of gender roles, and the second factor reflects an egalitarian division of gender roles. A preliminary study using the scale was conducted on 101 families with adult children (each family included a father, a mother, and an adult child with a university degree). The results revealed the importance of the scale in assessing the attitudes of different generations toward gender roles.
\end{abstract}

Keywords: attitudes, gender, factor analysis

\section{Adaptação e Validação Fatorial da Escala de Atitudes Relativas aos Papéis de Gênero}

Resumo: As atitudes relativas aos papéis de gênero resultam de um processo de construção social com implicações no modo como se definem os papéis sociais considerados adequados para homens e mulheres. O objetivo deste estudo foi realizar a adaptação e a validação fatorial de uma escala que avalia as atitudes em relação aos papéis de gênero. No estudo participaram 746 estudantes universitários e jovens profissionais. Para validar a estrutura fatorial vários modelos foram testados recorrendo a análises fatoriais exploratórias e confirmatórias. A estrutura fatorial obtida é composta por dois fatores correlacionados: o primeiro refere-se à divisão tradicional dos papéis de gênero e o segundo aponta para uma divisão igualitária dos papéis de gênero. Um estudo preliminar com o instrumento foi efetuado junto de 101 tríades familiares (pai, mãe e jovem adulto com diploma universitário), permitindo evidenciar a importância do instrumento para a avaliação dos papéis de gênero em diferentes gerações.

Palavras-chave: atitudes, gênero, análise fatorial

\section{Adaptación y Validación Factorial da Escala de Actitudes Relativas a Roles de Género}

\begin{abstract}
Resumen: Las actitudes hacia los roles de género son resultado de un proceso de construcción social, con implicaciones para la forma en que definen los roles sociales que se consideran adecuados para los hombres y las mujeres. El objetivo de este estudio fue adaptar y validación fatorial de una escala que evalúa las actitudes hacia los roles de género. Para validar la estructura fatorial se efectuo análisis fatorial exploratorio y confirmatório con 746 estudiantes universitarios y jóvenes profesionales. A estructura fatorial de la escala esta compuesta por dos fatores correlacionados: división tradicional de roles de género y reparto equitativo de los roles de género. Un estudio preliminar del instrumento se realizó com 101 tríadas de la familia (padre, madre y adultos jóvenes con título universitario). Los resultados obtenidos demuestran la importancia del instrumento para la evaluación de los roles de género en diferentes generaciones.
\end{abstract}

Palabras clave: actitudes, género, análisis factorial

Attitudes toward gender roles are associated with culturally contextualized images that differentiate feminine and masculine. The construction of gender roles is based on beliefs regarding acceptable roles for men and women, which include not only aspects of each gender's characterization but also the relationship between the two genders (Halpern, 2012; Wood \& Eagly, 2012). In a review of studies and

\footnotetext{
${ }^{1}$ This article is derived from the doctoral dissertation of the author, which was defended in 2007, at the Faculdade de Psicologia e de Ciências da Educação of the Universidade do Porto.

Support: The author received financial support in the form of a doctoral scholarship from the Foundation for Science and Technology (Fundação para a Ciência e Tecnolgia - SFRH/BD/5153/2001)

${ }^{2}$ Correspondence address:

Claudia Andrade. Escola Superior de Educação, Instituto Politécnico de Coimbra. Rua D. João III, Solum, 3030-329. Coimbra, Portugal. E-mail: mcandrade@esec.pt
}

research on the social construction of gender roles, Amâncio (1994) concluded that the boundaries between gender roles and other social roles frequently demonstrate a differentiating asymmetry of masculine and feminine. The study also concluded that certain subcategories considered feminine, such as the representation of a housewife, result in a broad consensus in descriptions that are constructed for the purpose of comparison with other subcategories, such as that of a working woman (Amâncio, 1994). A previous study by Deaux and Kite (1985) showed that feminine categories that differ from the traditional roles of women, such as those of the businesswoman and the female athlete, contain both masculine and feminine attributes in their descriptions.

Despite all of the social and cultural changes that have occurred in the last decades, the ideological determination that establishes this asymmetry between gender roles seems 
to persist (Buchanan, 2014; Matias, Andrade, \& Fontaine, 2011). In fact, as several studies have reported, the changes in representations of gender roles are more noticeable in the public domain, for example, in paid employment, than in the private domain, where the division of household chores and childcare still grants the feminine gender role a special emphasis on homemaking (Andrade \& Bould, 2012; Andrade \& Fontaine, 2007; Carothers \& Reis, 2012; Cech \& Blair-Loy, 2010; Matias et al., 2012; Oliveira, Fischer, Teixeira, Sá, \& Gomes, 2010). As stated by Amâncio (1994), "the enlargement of gender roles in the social context does not entail that a change in one of the domains, in this case the public domain, necessarily implies a generalized change on the behavioral level or on the subjective level" (p. 72). Therefore, gender role differentiation reflects a separation between the public and private domains within the family and in professional life (Amâncio, 1994; Andrade \& Fontaine, 2011; Matias et al., 2012).

\section{Socialization Contexts and the Social Construction of Gender Roles}

The change in family roles and social movements in favor of equality introduced new concepts such as a more just distribution of and access to different social roles. These changes raised the need for reflection on gender roles, especially for members of the younger generations. Therefore, although men still frequently believe that household work and childcare are primarily tasks for which women are responsible, i.e., that correspond to a feminine gender role, the truth is that studies indicate that members of younger generations truly desire and believe that it is important to build a family in which professional and family roles are shared (Andrade, 2010, 2013; Andrade \& Fontaine, 2012). These apparently contradictory perspectives could have their origins in socialization processes that are generationally differentiated.

Gender socialization theories that refer to the development of masculinity and femininity emphasize not only the influence of family models but also the importance of each individual's life experience in context. Some aspects should be noted when analyzing the influence of family models. In fact, some researchers state that in any generation, women are always less traditional in relation to gender roles than men are (Scott, Alwin, \& Braun, 1996). Remarkable differences emerge when the generations of parents and children are compared; the children, regardless of their gender, are less traditional than the parents (Andrade, 2010; Scott et al., 1996). Some researchers explain this reality using the fact that parents frequently socialize their children with attitudes that differ from their own, which impedes the linear intergenerational transfer of attitudes toward certain roles (Acock \& Demo, 1994; Andrade \& Fontaine, 2012).

In fact, some studies have not found proof of the intergenerational transfer of attitudes to the gender roles of children (of both genders) and of mothers who practice a professional activity and who are housewives, with the housewives considered more traditional in relation to gender roles. In these studies, children of both genders always exhibited more egalitarian attitudes toward gender roles than mothers did (Andrade, 2012). Therefore, there seems to be an influence from other socialization agents, particularly those that occur in peer, school, and sibling contexts, to cite some examples of contexts that exert socializing influences that are often difficult to evaluate empirically (Acock \& Demo, 1994). Additionally, social constraints might make it difficult, in a certain way, to implement behaviors that reflect more egalitarian attitudes toward gender and to justify the differences found between attitudes and behaviors. Therefore, in the family domain and their professional roles, the women who presented egalitarian attitudes toward gender had families that behaved in non-egalitarian manners and in which men participated little in family roles (Deutsch, 1999). In addition, families with double-employment that exhibited egalitarian attitudes toward gender roles tended to practice a traditional division of family and professional roles in their daily lives (Davis \& Wills, 2010). Some families with traditional attitudes toward gender roles shared some tasks, particularly those relating to childcare (Deutsch, 1999). Furthermore, in families with high educational levels associated with high economic levels, there was a tendency for household chores to be performed not by either parent but by another person (i.e., a housekeeper).

In general, previous studies indicate that there are several sources of socialization and social models that influence the formation of attitudes toward gender roles. Because of the number of aspects of the formation of attitudes toward gender roles, which focus particularly on the domains of attitudes relating to gender roles in family and professional environments, their variations with the context, and the absence of tools adapted to the Portuguese context, it is important to adapt an instrument that is capable of evaluating the attitudes of young adults toward gender roles.

In addition, an exploratory study using the instrument was conducted with two groups, one of parents and another of their adult children, to evaluate the extent to which the instrument makes it possible to uniquely examine the attitudes of different generations toward gender roles while taking each subject's gender into account. The choice of two sample groups from different generations was based on results obtained in other studies, which have frequently found that younger individuals with higher educational levels present egalitarian attitudes toward gender roles (Leaper \& Valin, 1996). These results are reinforced when parents and children are compared; the children are less traditional than their parents regardless of their gender (Scott et al., 1996). In addition, some researchers support the fact that younger generations are exposed to progressively more egalitarian social contexts, particularly peer contexts, as well as school and professional contexts, which all exert socializing influences that favor the development of more egalitarian attitudes in younger generations than in their progenitors' generations (Acock \& Demo, 1994). Therefore, we suppose, on an exploratory basis, that children present more egalitarian attitudes toward gender roles due to socialization in more egalitarian contexts and that their parents present more traditional attitudes in this domain. 


\section{Method - Study 1}

\section{Participants}

In the present study, two samples were used (a sample for the exploratory factor study and a sample for the confirmatory factor study); both consisted of college students and young professionals with college degrees. The participants in the first group consisted of 385 college students and young professionals (a calibration sample) who were between 18 and 25 years old. The average age was 21.05 years old and the standard deviation was 3.45 years. Of the subjects, $68 \%$ were female and $32 \%$ were male. The college students lived with their parents more frequently than the young professionals; the rates were $73 \%$ and $62 \%$, respectively. The remaining participants lived with either friends or colleagues, $27 \%$ of whom were students and $36 \%$ of whom were young graduates; only $2 \%$ of the young graduates lived with a partner, boyfriend, or girlfriend. Of the students, only $8 \%$ claimed to work parttime, and the remaining students were considered full-time workers. Of the young professionals, 55\% claimed to work full-time, and the remainder claimed to perform at least one part-time professional activity (34\%) or a professional activity concurrently with graduate studies (11\%).

A confirmatory factor analysis (CFA) of the scale (using the calibration sample) was conducted with 361 college students who were between 18 and 35 years old with an average age of 21.47 years old and a standard deviation of 2.59 years. Of the subjects in this sample, $56 \%$ were female subjects and $44 \%$ were male. In this sample, $25 \%$ of the students and $40 \%$ of the young professionals lived with a friend, colleague, or spouse, and only $5 \%$ of the graduate students lived with a partner, boyfriend or girlfriend. Of the participants living with their parents, $75 \%$ were students and $55 \%$ were young professionals. Only $2 \%$ of the students claimed to work part-time, the remainder were considered full-time workers. Of the young professionals, $60 \%$ claimed to work full-time, and the remainder claimed to perform at least one part-time professional activity (35\%) or a professional activity concurrently with graduate studies $(5 \%)$. Regarding parenthood, $2 \%$ of the students and $3 \%$ of the young professionals were parents, and all of them had only one child who was between 9 months and 6 years old.

\section{Instrument}

Attitudes toward Gender Scale - ATGS (Leaper \& Vallin, 1996). In its original version, this is a scale of attitudes toward gender that consists of 28 items. It was constructed based on a review and update of different psychological evaluation instruments aimed at measuring attitudes toward gender and gender roles. The objective of this instrument is to evaluate the attitudes towards equal rights and the roles of men and women in the context of gender roles. The responses are evaluated using a Likert-type scale and scored from 1 to 4; the higher the global score obtained is, the more positive the respondent's attitude toward gender role equality is. In the scale's original version, the values representing the internal consistency obtained by the researchers during the studies conducted using this instrument varied from .74 to .91 .

Adaptation and validation of the Attitudes toward Gender Scale (ATGS), which is called the Attitudes toward Gender Roles Scale (Escala de Atitudes Relativas aos Papéis de Género) in its Portuguese version, was performed in structured stages. The first phase of the instrument's adaptation consisted of the translation and retroversion of each item from English into Portuguese and from Portuguese into English, respectively, to verify the quality and reliability of the translation of all 23 of the items that constitute the scale. After this phase, the scale was reflected on orally by a group of 20 adults ranging from 18 to 59 years in age of both genders who were single or married, who had or did not have children, and who had reached different levels of education.

The objectives of this reflection were to evaluate the general suitability of the items to the Portuguese socio-cultural context and to test its clarity and the suitability of the answer alternatives. The oral reflection stage did not lead to any changes in the Portuguese items' formulations because they were considered clearly formulated, and no issues relating to understanding or responding using the proposed alternatives were raised.

The objective of the second stage was to evaluate the discrimination capacity of the items. For this purpose, the low discriminatory power of a question was considered verified when over $70 \%$ of the responses were concentrated on either the positive or the negative options (Completely Agree and Agree or Disagree and Completely Disagree; Marôco, 2010). Because no items meeting these criteria were found, there was no need to eliminate items in this phase of the analysis.

\section{Procedure}

Data collection. The scale was administered to groups in classrooms at institutions of higher education. To administer the questionnaire to individual young professionals, training institutions and companies in the same regions were contacted.

Data analysis. The database was constructed using PASW Statistics 10.0 (SPSS Inc., Chicago, IL). The factorial validation was performed using a CFA Amos (v. 7, SPSS Inc., Chicago, IL). The parameters were estimated from the correlation matrix using the maximum likelihood method. The normality of the variables was verified using the coefficients of asymmetry (sk) and kurtosis (ku); $|\mathrm{Sk}|>3$ indicated severe asymmetry, $|\mathrm{Ku}|>10$ indicated severe kurtosis, and $|\mathrm{Ku}|>$ 20 indicated very severe kurtosis (Kline, 2011). The global adjustment of the model was evaluated using the following indexes and reference values to identify an acceptable adjustment (Kline, 2011): $\chi^{2} /$ g.l. $<5$; Bentler comparative fit index $(\mathrm{CFI})>.90$, root mean square error of approximation (RMSEA) $<.08$, and standardized root mean square residual $($ SRMR) $<.08$ (Kline, 2011). The internal consistency of the factors was determined by calculating Cronbach's alpha.

\section{Ethical Considerations}

The data collection process was preceded by acknowledgements of free and informed consent. The participants received an explanation of the voluntary 
nature of their participation and the study proposal, and the confidentiality and anonymity of their responses were ensured. After receiving permission from their higher education institutions, the study's researcher and three research assistants, two of whom were female psychologists and one of whom was a male psychologist, administered the questionnaire together during the available timeframe.

\section{Results}

The Attitudes toward Gender Roles Scale consists of 23 items and is considered multifactorial by its authors. The evaluation of the psychometric qualities of the instrument was initiated by an exploratory factor analysis that, after a varimax rotation, demonstrated a solution in two factors that were saturated by the following items: Factor 1 (items 2, 3, 23, 1, 21, 17, 7, 6, 4, 18, 19, 15, 25, 13, and 9) and Factor 2 (items $20,10,22,8,12,24,16$, and 19). One of these items presented a saturation that was lower than .30 , which led to its exclusion from the final version of the instrument. As shown in Table 1, the items that constitute Factor 1 reflect an attitude of appreciation of the traditional division of gender roles, which involves asymmetric participation of men and women in different social roles. The items that constitute Factor 2, in turn, reflect an attitude of appreciation of the egalitarian division of gender roles. These two factors, as a whole, explain $31 \%$ of the total variance; Factor 1 explains $16 \%$ of the variance, and Factor 2 explains $15 \%$ of it. Each factor's internal consistency was determined by calculating Cronbach's alpha, which was .80 for Factor 1 and .77 for Factor 2. As a second step, the instrument's factorial structure was

Table 1

Factor Analysis in Main Components After a Varimax Rotation

\begin{tabular}{|c|c|c|c|}
\hline Items in the P.A.T.G.S. & Factor 1 & Factor 2 & h2 \\
\hline 2. The man should have the main responsibility for the family's economic support. & .64 & -.26 & .49 \\
\hline 3. The use of profane language is worse for a girl than for a boy. & .64 & -.17 & .44 \\
\hline 23. Women should worry more about their clothing and appearance than men should. & .63 & -.10 & .42 \\
\hline $\begin{array}{l}\text { 1. It is more appropriate for a woman to be a babysitter or a child educator than it is for a man to } \\
\text { fill these roles. }\end{array}$ & .62 & -.15 & .41 \\
\hline 21. It is harder for a woman to find a job than it is for a man to find a job. & .57 & -.14 & .34 \\
\hline 17. Some jobs are not suitable for women. & .54 & -.37 & .33 \\
\hline 7. The man should pay the bill when he is on a date with a woman. & .53 & -.15 & .30 \\
\hline 6. Only men should be allowed to participate in military combat. & .49 & -.23 & .30 \\
\hline 4. Women are very easily offended by certain jokes. & .48 & .33 & .34 \\
\hline 18. Girls should have more boundaries when going out than boys should. & .47 & .03 & .42 \\
\hline 19. In the workforce, women are taking jobs away from men who need them more. & .45 & .14 & .39 \\
\hline 15. It is wrong for boys to play with dolls. & .43 & .21 & .32 \\
\hline $\begin{array}{l}\text { 25. When both parents are employed and their child gets sick at school, the mother must be called } \\
\text { first, and only later is the father called. }\end{array}$ & .34 & .23 & .31 \\
\hline $\begin{array}{l}\text { 13. It should be equally acceptable for a woman and for a man to stay at home to take care of the } \\
\text { children while the other spouse works. }\end{array}$ & -.32 & .01 & .21 \\
\hline $\begin{array}{l}\text { 9. It should be equally acceptable for girls and boys to practice rough sports such as roller hockey } \\
\text { and soccer. }\end{array}$ & -.32 & .21 & .32 \\
\hline $\begin{array}{l}\text { 20. When men are courteous to women (such as when they open a door), it is a sign that men are } \\
\text { superior to women. }\end{array}$ & -.35 & .56 & .44 \\
\hline $\begin{array}{l}\text { 10. It is acceptable when the woman takes the initiative to start a romantic relationship with a } \\
\text { man. }\end{array}$ & -.09 & .45 & .28 \\
\hline $\begin{array}{l}\text { 22. Men and women should be able to make choices about their lives without being restricted by } \\
\text { their sex. }\end{array}$ & -.28 & .51 & .34 \\
\hline 8. Sexual harassment in the workplace is a serious issue. & -.02 & .50 & .25 \\
\hline 12. Discrimination against women in the workforce is no longer an issue. & -.19 & .31 & .13 \\
\hline 24. Crying in front of other people is equally acceptable for men and women. & .22 & .31 & .33 \\
\hline $\begin{array}{l}\text { 16. The woman needs to be careful to not appear more intelligent than the man when they are } \\
\text { dating. }\end{array}$ & -.19 & -.31 & .13 \\
\hline 19. In the workforce, women are taking jobs away from men who need them more. & .22 & .30 & .33 \\
\hline$\%$ of the total variance & 16.0 & 15.0 & \\
\hline Eigenvalue & 3.764 & 3.764 & \\
\hline
\end{tabular}

Note. The values in boldface represent the highest factorial weight of the item in each factor.

established on the basis of a sample of Portuguese students (a calibration sample) using a CFA. This method is used when prior information on a factorial structure is available and must be confirmed and to verify whether certain latent factors (sub-scales) are responsible for the behavior of certain specific manifested variables (items) according to a previously established standard (Marôco, 2010). The confirmatory analysis performed using another sample 
confirmed the universal belonging of the items found in the exploratory analysis of each of the factors. Only three of the items did not have saturated values with satisfactory factors; therefore, these items were removed, leaving 20 items in the final version of the scale. The model indicators of adjustment for Factor 1 were as follows: $\chi^{2} / \mathrm{g} .1 .=1.96$, $p=.000, \mathrm{GFI}=.95, \mathrm{AGFI}=.93, \mathrm{CFI}=.94$, and $\mathrm{RMSEA}=$ .05 , and the indicators for Factor 2 were as follows: $\chi^{2} /$ g.l. $=1.85 p=.023$, GFI $=.98$, AGFI $=.96, \mathrm{CFI}=.96$, and RMSEA $=.04$. Therefore, the results were satisfactory for both factors. Then, a CFA was performed for the scale as a whole with the assumption that there was a negative relationship between the factors. Figure 1 shows the item saturation values for each factor on the global scale. The values of the model's global adjustment, considering the scale as a whole, are $\chi^{2} / \mathrm{g} .1 .=2.25, p=.000, \mathrm{GFI}=.92$, $\mathrm{AGFI}=.89, \mathrm{CFI}=.90$, and RMSEA $=.03$, which are also very satisfactory.

The internal consistency of the items, as determined

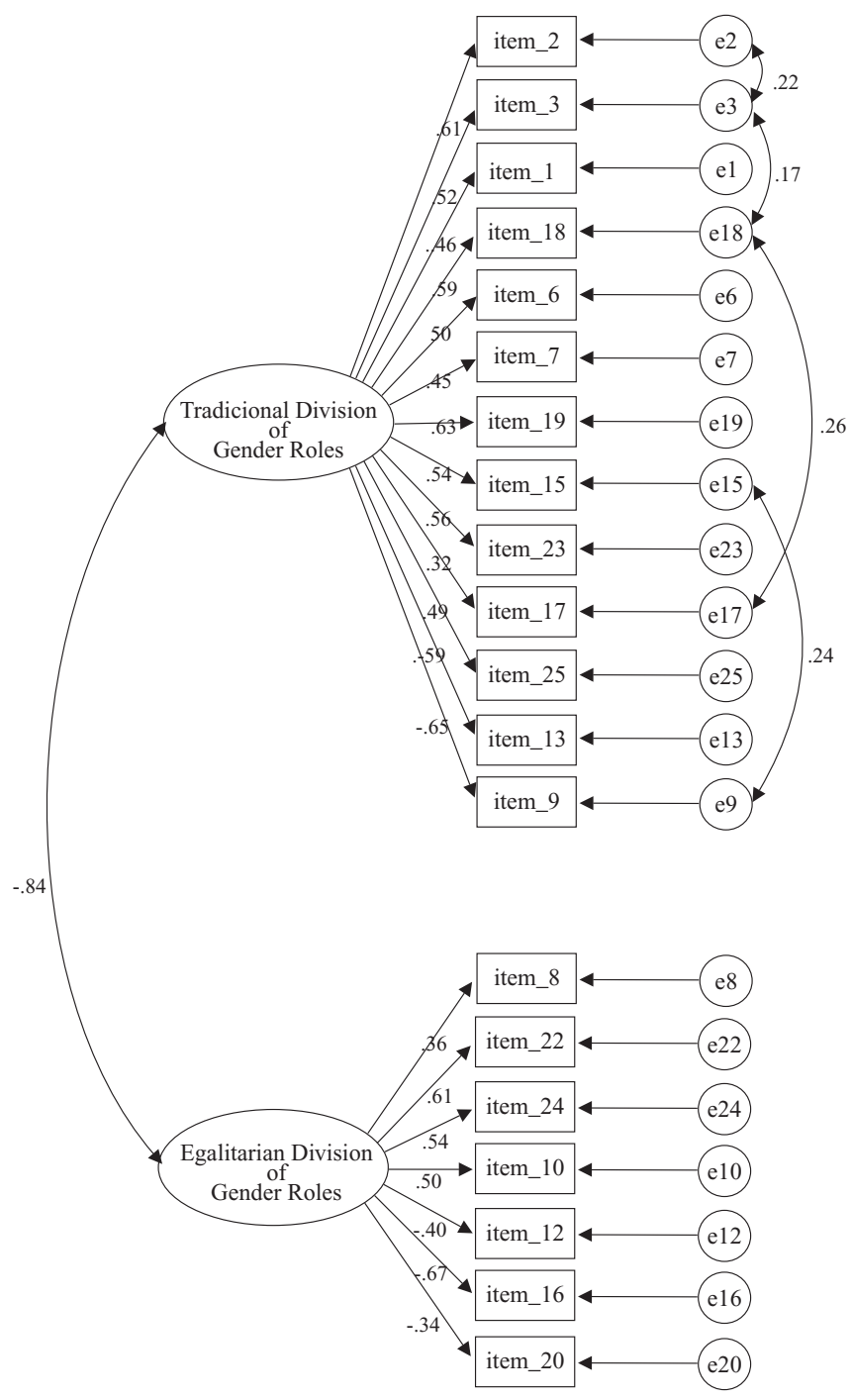

Figure 1. Representation of the theoretical model with two correlated factors. by calculating Cronbach's alpha, is .79 for Factor 1 and .68 for Factor 2. Although the second of these is not very high, it is near .70, which is considered sufficient for the purpose of comparing groups. All of the analyses of the instrument approve its acceptance as a reliable measuring tool for evaluating the attitudes of young adult students and individuals with college degrees toward gender roles.

\section{Method - Study 2}

\section{Participants}

In the present study, 101 families (each comprising a mother, a father, and a young adult child) participated. In 53 of these families, the descendant was a college student, and in 48 of these families, the descendant was a young professional with a college degree. Of the 101 young adults, $62.4 \%$ were female $(n=63)$ and $37.6 \%$ were male $(n=38)$. All of the young adult participants were single and living with their parents (however, some participants claimed that they spent some periods away from home due to work or school). All of the parents (fathers and mothers) performed professional activities. Most of the families had urban origins $(73.1 \%)$ and claimed to belong to the middle class $(68.3 \%)$. Regarding the parents' academic qualifications, the predominant educational level was middle school/high school, which described $54.4 \%$ of the mothers and $40.5 \%$ of the fathers. The average age of the child was 23.93 years old, the average age of the mother was 51.4 years old, and the average age of the father was 54.6 years old.

\section{Instrument}

Study 2 involved preliminary studies using the instrument presented in study 1 .

\section{Procedure}

Data collection. In the context of the administration of the previously cited Attitudes toward Gender Roles Scale, the young adult participants were asked to voluntarily provide contact information to enable the researchers to establish contact with their parents. The parents were contacted via telephone to ensure their voluntary participation in the study. The parents had access to the scale through their children or were contacted directly by the researchers at their homes. Although the research team had access to each family's personal contact information, it was ensured that the data obtained would be used only for the purpose of the study.

Data analysis. As a first contact and to verify the relevance of the factorial structure obtained from the young adult participants whose generational characteristics differed from their parents', a confirmatory analysis of the scale's structure was performed using the sample of parents. Once the scale's relevance to this group was verified, to analyze 
the extent to which the means of the four groups (parents, mothers, daughters, and sons) differed on each dimension of the scale, an analysis of variance (ANOVA) was used, and Scheffé post-hoc tests were used to compare pairs of means.

\section{Ethical Considerations}

The data collection process was preceded by acknowledgments of free and informed consent. The participants received an explanation of the voluntary nature of their participation and the study proposal, and the confidentiality and anonymity of their responses were ensured. After the participants agreed to participate in the study, the questionnaires were administered in the participant's homes by three research assistants, two of whom were female psychologists and one of whom was a male psychologist.

Table 2

Means and Standard Deviations of the Variables for Both Groups (Children and Parents) Based on Sex

\begin{tabular}{lcccc}
\hline & \multicolumn{3}{c}{ Children } & \multicolumn{2}{c}{ Parents } \\
\cline { 2 - 5 } & $M(S D)$ & Women & Men & Women \\
& $37.86(4.15)$ & $32.08(4.23)$ & $33.14(6.04)$ & $33.67(6.46)$ \\
Traditional Division of Gender Roles & $16.23(2.58)$ & $16.73(2.39)$ & $13.77(2.36)$ & $13.50(2.58)$ \\
\hline
\end{tabular}

Table 3

Analysis of the Variance of the Scales for the Groups (Mothers, Fathers, Daughters and Sons)

\begin{tabular}{lcccc}
\hline & g.1. & $F$ & $p$ & Scheffé \\
\hline Traditional Division of Gender Roles & 3 & 5.678 & .000 & $\mathrm{G} 3, \mathrm{G} 4>\mathrm{G} 1>\mathrm{G} 2$ \\
Egalitarian Division of Gender Roles & 3 & 2.645 & .000 & $\mathrm{G} 2>$, G1 $>$ G3, G4 \\
\hline
\end{tabular}

Note. G1 = Sons, G2 = Daughters, G3 = Fathers, G4 = Mothers.

In the traditional division of gender roles, $F(3,298)=$ 5.67; $p=.000$, fathers and mothers do not differ from each other. However, they differ from daughters and sons, who also differ from each other: daughters present lower values than sons and parents (fathers and mothers) for this variable. In addition, in terms of the egalitarian division of gender roles, $F(3,298)=2.64 ; p=.000$, sons and daughters differ from each other: daughters are more egalitarian than sons, and both daughters and sons differ significantly from parents (fathers and mothers), who do not differ from each other.

\section{Discussion}

Some aspects of a social and cultural nature persist and justify the presence of attitudes toward gender roles that do not appear as egalitarian as is desirable. However, it seems as if the increasing awareness of this theme and the experience of increasingly more egalitarian social and professional contexts might have contributed to the integration of the concept of gender equality among members of the younger generations. The results obtained in the present study corroborate longitudinal studies that concluded that, in the last 20 years,

\section{Results}

The confirmatory analysis of the structure of the scale using the sample of parents resulted in the following satisfactory adjustment indicators of the model: $\chi^{2 / g} .1=2.13$, $p=.000, \mathrm{GFI}=.86, \mathrm{AGFI}=.91, \mathrm{CFI}=.85$, and RMSEA $=.06$. Once the scale's relevance to this group had been verified, to analyze the extent to which means of the four groups (parents, mothers, daughters, and sons) differed in to each dimension of the scale, an ANOVA was used, and Scheffé post-hoc tests were used to compare pairs of means. Table 2 shows the mean value and standard deviation of each variable for each group. As shown in Table 3, in general, the differences in the means for the parents and the children are significant for both of these factors. members of younger generations, especially those with college degrees, have progressively shared a more egalitarian understanding of gender roles (Loo \& Thorpe, 1998). In fact, the results highlight gender differences in attitudes toward gender roles in the children's generation that do not occur in the parents' generation; mothers and fathers do not differ from each other but daughters and sons differ significantly (girls are more egalitarian than boys). Therefore, it appears that social changes that focus on, among other factors, the achievement of autonomy by women due to increasing opportunities for training and inclusion in the workforce are not accompanied by corresponding claims of men on the intrafamily level. To some extent, it appears that these changes limit specific achievements and do not represent a change in gender relationships, which have remained very traditional, especially in the intra-family domain. In young adults, the presence of more egalitarian attitudes in daughters than in sons was also observed. These results are aligned with the results of several other researchers: young males present less egalitarian attitudes toward gender roles than young females do (Andrade, 2013; Covin \& Brush, 1991). Therefore, it is possible to state that in the context of gender relationships, 
role representations and practices on the household level seem to reveal a strong tradition in the parents' generation. In addition, it is important to note that the social advances that reflect the presence of egalitarian attitudes toward gender roles also present gender specifications for the younger generation. This is most likely because girls feel more penalized by traditional attitudes in this domain.

On the whole, these assumptions ensure that the results of this study not only confirm results that have been found in several other studies but also highlight the importance of social contexts that call for egalitarian values in relation to gender roles and that influence younger generations.

In the present study, in the context of study 1, the first results concerning the factorial structure, internal consistency, and sensitivity of the Attitudes toward Gender Roles Scale were presented. The exploratory factor analysis highlighted the existence of two factors that lead to two theoretical dimensions of role conciliation strategies, the traditional division of gender roles and the egalitarian division of gender roles. This factorial structure was subsequently confirmed by the confirmatory analyses conducted for the young adult group and the parent group.

Nevertheless, the present study has some limitations that should be highlighted to assist further studies on this subject. The fact that we have focused exclusively on exploratory and confirmatory analyses involving young adult students or young adult professionals with college degrees raises the issue that these participants could have been exposed to more or less homogeneous contexts due to their educational levels. This restricts the relevance of the instrument in contexts in which the participants' educational levels might be different. In all circumstances, the present study of adapting and validating the Attitudes toward Gender Roles Scale should be understood as a preliminary study. Future studies must contemplate an improvement of this scale by aiming at an analysis of the accuracy of the items and dimensions in other socio-demographic contexts.

\section{References}

Acock, A. C., \& Demo, D. H. (1994). Family diversity and wellbeing. Thousand Oaks, CA: Sage.

Amâncio, L. (1994). Masculino e feminino: A construção social da diferença [Male and female: The social construction of gender]. Porto, Portugal: Afrontamento.

Andrade, C. (2010). Trabalho e família na transição para a idade adulta [Work and family in the transition to adulthood]. Porto, Portugal: LivPsic.

Andrade, C. (2012). "Tal mãe, tal filha": Semelhanças geracionais e transmissão intergeracional de estratégias de conciliação família-trabalho [Like mother, like daughter: Generational similarities and intergenerational transmission of strategies to reconcile work and family]. Psicologia, Educação e Cultura, 16(1), 167-189.

Andrade, C. (2013). Relações trabalho-familia e género: Caminhos para a conciliação [Work-family relations and gender: Paths for reconciliation]. Lisboa, Portugal: Coisas de Ler.
Andrade, C., \& Bould, S. (2012). Child-care burden and intentions to have a second child: Effects of perceived justice in the division of child-care. International Review of Sociology, 22(1), 25-37. doi:10.1080/03906701.2012. 657527

Andrade, C., \& Fontaine, A. M. (2007). Rôles familiaux et professionnels: Attitudes et stratégies de conciliation. Ce qui se transmet [Family and work roles: Attitudes and reconciliation strategies. What is passed along]. Revue Internationale de l'Éducation Familiale, 22(2), 67-85. doi:10.3917/rief.022.0067

Buchanan, T. (2014). The influence of gender role attitudes on perceptions of women's work performance and the importance of fair pay. Sociological Spectrum: MidSouth Sociological Association, 34(3), 203-221. doi:10.1 080/02732173.2014.895637

Carothers, B. J., \& Reis, H. T. (2012). Men and women are from Earth: Examining the latent structure of gender. Journal of Personality and Social Psychology, 104(2), 385-407. doi:10.1037/a0030437

Cech, E. A., \& Blair-Loy, M. (2010). Perceiving glass ceilings? Meritocratic versus structural explanations of gender inequality among women in science and technology. Social Problems, 57(3), 371-397. doi:10.125/ sp.2010.57.3.371

Covin, T. J., \& Brush, C. C. (1991). An examination of male and female attitudes towards career and family issues. $S e x$ Roles, 25(7-8), 393-415. doi:10.1007/BF00292530

Davis, S. N., \& Wills, J. B. (2010). Adolescent gender ideology socialization: Direct and moderating effects of fathers' beliefs. Sociological Spectrum, 30(5), 580-604. doi:10.108 0/02732173.2010.496106

Deaux, K., \& Kite, M. E. (1985). Gender stereotypes: Some thoughts on the cognitive organization of gender-related information. Academic Psychology Bulletin, 7(2), 123-144.

Deutsch, F. M. (1999). Having it all: How equally shared parenting works. Cambridge, MA: Harvard University Press.

Halpern, D. F. (2012). Sex differences in cognitive abilities (4th ed.). New York, NY: Psychology Press.

Kline, R. B. (2011). Principles and practice of structural equation modeling (3rd ed.). New York, NY: Guilford.

Leaper, C., \& Valin, D. (1996). Predictors of Mexican American mothers' and fathers' attitudes toward gender equality. Hispanic Journal of Behavioral Sciences, 18(3), 343-355. doi:10.1177/07399863960183005

Loo, R., \& Thorpe, K. (1998). Attitudes toward women's roles in society: A replication after 20 years. Sex Roles, 39(11-12), 903-912.

Marôco, J. (2010). Análise de equações estruturais: Fundamentos teóricos, software \& aplicações [Analysis of structural equations: Theoretical foundations, software \& applications]. Pêro Pinheiro, Portugal: Report Number.

Matias, M., Andrade, C., \& Fontaine, A. M. (2011). Diferenças de género no conflito trabalho-família: Um estudo com famílias portuguesas de duplo-emprego 
com filhos em idade pré-escolar [Gender differences in work-family conflict: A study of Portuguese dual-earner families with young children]. Psicologia: Revista da Associação Portuguesa de Psicologia, 25(1), 9-32.

Matias, M., Andrade, C., \& Fontaine, A. M. (2012). The interplay of gender, work and family in Portuguese families. Work, Organisation, Labour \& Globalisation, 6(1), 11-26.

Oliveira, D. C., Fischer, F. M., Teixeira, M. C. T. V., Sá, C. P., \& Gomes, A. M. T. (2010). Representações sociais do trabalho: Uma análise comparativa entre jovens trabalhadores e não trabalhadores [Social representations of work: A comparative analysis of young workers and the young unemployed]. Ciência \& Saúde Coletiva, 15(3), 763-773. doi:10.1590/S1413-81232010000300019

Scott, J., Alwin, D. F., \& Braun, M. (1996). Generational changes in gender-role attitudes: Britain in a crossnational perspective. Sociology, 30(3), 471-492. doi: $10.1177 / 0038038596030003004$

Wood, W., \& Eagly, A. H. (2012). Biosocial construction of sex differences and similarities in behavior. In M. Zanna \& J. Olson (Eds.), Advances in experimental social psychology (Vol. 46, pp. 55-123). San Diego, CA: Academic Press.

Claudia Andrade is an Adjunct Professor at Escola Superior de Educação de Coimbra, Instituto Politécnico de Coimbra, Portugal. She is also a member of the Centro de Psicologia, Universidade do Porto, Portugal.

Received: Nov. 26, 2014

1st Revision: Apr. 10, 2015

2nd Revision: Apr. 24, 2015

Approved: May 12, 2015

How to cite this article:

Andrade, C. (2016). Adaptation and factorial validation of the Attitudes toward Gender Roles Scale. Paidéia (Ribeirão Preto), 26(63), 7-14. doi:10.1590/1982-43272663201602 